\title{
Improvement of bankruptcy probability model based on the analysis of industrial enterprises of Ukraine
}

\author{
Tetiana Melikhova ${ }^{1, *}$, Andriy Makarenko ${ }^{1}$, Olena Mikhailytsa ${ }^{2}$, and Andriy Pozhuyev $^{3}$ \\ ${ }^{1}$ Zaporizhzhya National University, Department of Accounting, Analysis, Taxation and Audit, Zaporizhzhya, Ukraine \\ ${ }^{2}$ Zaporizhzhya National University, Department of Automation Systems Software, Zaporizhzhya, Ukraine \\ ${ }^{3}$ Zaporizhzhya National University, Inter-faculty department of general education discipline, Zaporizhzhya, Ukraine
}

\begin{abstract}
In present work, the peculiarities of simulation model of enterprises bankruptcy probability that exist in European, world and domestic practices were considered. The scientific econometric approach was applied to determine the overall presence and strength of the relation between the economic indicators of industrial enterprises. A financial analysis of large industrial manufactures in the region of Ukraine was conducted. To form the information base of the study, the authors estimated liquidity, solvency, business activity and profitability ratios that affect the financial condition of enterprises. They revealed the most significant ratios of financial condition analysis. According to the analysis of existing models of bankruptcy probability in the context of these industrial enterprises, an improved model for assessing the risk of bankruptcy was proposed and evaluated. The proposed model for estimating the probability of bankruptcy, taking into account the influence of the most significant ratios of financial analysis, confirmed that the percentage of provided bankruptcies and stable activities are acceptable and indicate high quality of the resulting equation. The IBM SPSS Statistics system was used to process the data, check the assumptions and prepare valid conclusions. The improved model will allow it to be used in the practice of diagnosing the probability of bankruptcy of industrial enterprises, which will help identify the threat of bankruptcy in time and ensure stable operation of the industrial enterprise.
\end{abstract}

\section{Introduction}

One of the priorities of Ukrainian economy is the rapid development of industrial manufactures in each region. Sales volume is one of the main indicators by which the results of economic and production process of manufactures as well as the area and Ukraine as a whole are estimated. Existing threats to the internal and external environment of industrial enterprises affect the probability of their bankruptcy.

The development of economic innovative path implies, first of all, the possibility and necessity of making sound economic decisions on a strict and logically verified basis. Mathematical and, in particular, statistical research methods make it possible to substantiate and verify the adequacy of the measures applied to a particular economic object in particular circumstances.

\section{Review of literature}

The main issues and description of the world problem under consideration in the present work are based on the review and analysis of foreign and domestic publications. According to authors such as I. Andryushchenko [1] a peculiar place at the macrolevel is taken by the analysis of economic performance of the Ukrainian industrial development. I. Sitak, D. Korobkov and V. Mishchenko [2] insist on the importance of analyzing the financial condition of industrial enterprises for the industry development as a whole.

The authors of [3] tried to consider the main existing trends in the area of digitization of the socio-economic sphere. The consideration is focused on the development of the country's economy that directly depends on a society digital development level.

The study of particular use of neurocomputing in financial sphere can be found in researches of A. Galushkin, O. Khlystova, A. Mints, V. Mosvenok, etc. At present, there is a widespread appearing in the domestic market of a vast number of both universal neuropackages for solving technical analysis problems and specialized expert systems and neuropackages designed for solving more complex and difficult to formalize problems from the financial field. The authors of [4-6] give a brief list of the main tasks where neurocomputers have effectiveness that is much higher than the effectiveness of both common regression analysis methods and expert systems based on the construction of a formal model of an object or phenomenon. The principles of neural networks construction and their main functioning characteristics are also described.

The characteristics of Ukrainian enterprises crisis conditions considered in [7]. To analyze the probability of bankruptcy, four economic and mathematical models were proposed and calculated using various modeling tools and different number of factors. The authors analyzed two models of linear regression and two models

\footnotetext{
* Corresponding author: tanyu_zp_zgia $@$ ukr.net
} 
based on neural networks, proposed and tested several methods for predicting the bankruptcy probability at a macroeconomic level, which made it possible to obtain adequate results.

It should be mentioned, that works of several foreign scientists are devoted to the study of issues under consideration. Thus, in [8] the main principles on which the models of neural networks are based and which must be followed to be effective are presented. A comparison of the regression analysis and neural networks with the hybrid method suggested in [9] showed the superiority of the neuroregression method. A comparative analysis of the two main models for forecasting in [10] is based on the minimum predicted error. The results of the multidimensional regression approach of OLS and the non-parametric approach of the neural network were processed, and the method with the lowest average overall absolute percentage error has been defined.

Later in [11], a completely new theory of asymptotic distribution was suggested for standard methods, such as regression, correlation analysis, and covariance. The present technique is based on a fixed time interval, which permits the number of high-frequency returns for this period to go to infinity. The authors of [12] present an algorithm for conducting statistical forecasting of economic indicators, which is based on the consistent application of individual methods of mathematical statistics to build the most reliable and adequate econometric models of indicators relationship affecting the investment and innovation potential of the region.

Researchers E. Raevneva and O. Gorokhovaya [13] believe that when conducting financial and economic activities, industrial enterprises are affected by various risks, threats to their stability, which enables bankruptcy. To ensure the economic security of an enterprise, E. Ponomarenko [14] recommend analyzing and predicting the future operation of an enterprise.

There are many foreign and domestic models for defining the probability of bankruptcy of an enterprise, namely the Altman [15], Springgate [16], Taffler and Tishou [17], Saifulin-Kadykov [18] and others models. Some of them are really based on a multivariate regression equation, others use a mixture of financial ratio analysis. They are recommended for analysis, if you need to take into account current business trends and the impact of promising technologies on the structure of financial indicators.

During of the study, a significant number of publications on this topic were found, confirming the relevance of the chosen direction. Despite the existence of different authoring methods for assessing the probability of bankruptcy, their calculation results are not always able to show the real financial situation of enterprises, as it should be borne in mind that most of the methods used are developed by foreign scientists, so the issue of their adaptation to the activities of Ukrainian enterprises remains unresolved.

\section{Materials and methods}

To analyze the economic situation, various indicators are used, which are interconnected stochastically (not strictly). Using the available statistical observations, namely the sales volume on the main activities types for the period 2012-2017 for industrial enterprises of Ukraine, Zaporizhzhya region and its two profiled enterprises, the behavior of the object under study is simulated. For simulation being correct, it is advisable to use an econometric, in particular, correlative, approach, which allows to test statistical hypotheses about the presence and strength of the correlation.

The obtained correlation ratio will make it possible to establish the closeness of linear correlation between the economic indicators under consideration, to correctly determine the type of relationship - direct or indirect, and also to make the right decisions concerned the choice of various indicators analyses.

Considering the sales volume data in the metallurgical branch and mechanical engineering, the main hypothesis is put forward about the absence of a correlation link between the analyzed indicators; the hypothesis of a correlation link presence is considered as an option. The linear correlation ratio is used to assess the degree of relation closeness [19]

$$
\begin{aligned}
& r=\frac{\operatorname{cov}(x \cdot y)}{\sigma_{x} \sigma_{y}}=\frac{\overline{x y}-\bar{x} \cdot \bar{y}}{\sigma_{x} \sigma_{y}}= \\
& =\frac{1 / n \sum_{i=1}^{n} x_{i} y_{i}-\bar{x} \cdot \bar{y}}{\sqrt{1 / n \sum_{i=1}^{n}\left(x_{i}-\bar{x}\right)^{2} \cdot 1 / n \sum_{i=1}^{n}\left(y_{i}-\bar{y}\right)^{2}}}
\end{aligned}
$$

where $x_{i}, y_{i}$ are the values of the first and second measured parameters in each observation respectively; $\bar{x}_{i}, \bar{y}_{i}$ are the average values of necessary measured parameters; $n$ is the number of paired observations of variables $X$ and $Y ; \sigma_{x}, \sigma_{y}$ are the normal deviations calculated for all particular values of the first and second parameters, respectively.

For the period from 2010 to 2017 , according to the statistics service (Table 1), the volume of products sold in Ukrainian industry increased by 2.06 times in metallurgy, and 1.73 times in machine-building. So, the analysis showed that for 2010-2017, the share of metallurgy in the overall volume of industrial manufactured products in Ukraine decreased by 3.4 points, and the share of machine-building decreased by 2.9 points. The factors that restrain industrial production are insufficient demand for products, lack of professional workforce, high-quality raw materials and modern equipment. Considering the sampling of data for Ukraine in metallurgical production $(X)$ and mechanical engineering $(Y)$ using software tools, we define the empirical value of the correlation ratio, equal to 0.775 .

To analyze the strength of the relationship between variables, the Cheddock scale was used, according to which, the correlation ratio in range from 0.7 to 0.9 , the relations between the parameters studied are high. For the value level, the critical value of the correlation ratio is 
0.71. Thus, the relation between the volume of manufactured industrial products sold in engineering and metallurgy is statistically significant at 5\% level and is positive.

Table 1. The volume of industrial products sold (goods, services) by type of economic activity in Ukraine in 20102017.

\begin{tabular}{|c|c|c|c|c|}
\hline \multirow{2}{*}{$\begin{array}{r}\text { Kind of } \\
\text { activity }\end{array}$} & \multicolumn{2}{c|}{$\begin{array}{r}\text { Metallurgical } \\
\text { production }\end{array}$} & \multicolumn{2}{c|}{ Engineering } \\
\cline { 2 - 5 } Year & UAH million & $\begin{array}{c}\text { \% of } \\
\text { total }\end{array}$ & $\begin{array}{c}\text { UAH } \\
\text { million }\end{array}$ & $\begin{array}{c}\% \text { of } \\
\text { total }\end{array}$ \\
\hline 2010 & 200001.9 & 19.1 & 97056.9 & 9.3 \\
\hline 2011 & 241884.7 & 18.5 & 130847.9 & 10.1 \\
\hline 2012 & 223294.1 & 16.3 & 140539.3 & 10.3 \\
\hline 2013 & 207305.3 & 15.7 & 113926.6 & 8.6 \\
\hline 2014 & 237393.0 & 16.6 & 101924.7 & 7.1 \\
\hline 2015 & 278502.8 & 15.7 & 115261.7 & 6.5 \\
\hline 2016 & 318195.9 & 14.8 & 131351.8 & 6.1 \\
\hline 2017 & 411372.3 & 15.7 & 168281.9 & 6.4 \\
\hline
\end{tabular}

In view of the fact that not all regions of Ukraine are industrial, it is interesting to analyze the Zaporizhzhya region, which is one of the leaders in this area. For the period from 2012 to 2018, according to the statistics service (Table 2), the volume of products sold in the Zaporizhzhya region in the metallurgical industry increased by 3.58 times, and in mechanical engineering it increased by 1.73 times. The analysis for 2012-2018 showed that the share of metallurgy in the total volume of products manufactured in the Zaporizhzhya region increased by 9.7 points, the share of engineering decreased by 10.5 points.

Table 2. The volume of industrial products sold (goods, services) by economic activity in the Zaporizhzhya region in 2012-2018.

\begin{tabular}{|c|c|c|c|c|}
\hline \multirow{2}{*}{$\begin{array}{r}\text { Kind of } \\
\text { activity }\end{array}$} & \multicolumn{2}{|c|}{$\begin{array}{r}\text { Metallurgical } \\
\text { production }\end{array}$} & \multicolumn{2}{c|}{ Engineering } \\
\cline { 2 - 5 } & Year million & $\begin{array}{c}\text { \% of } \\
\text { total }\end{array}$ & $\begin{array}{c}\text { UAH } \\
\text { million }\end{array}$ & $\begin{array}{r}\% \text { of } \\
\text { total }\end{array}$ \\
\hline 2012 & 23878088.3 & 30.7 & 18061561.8 & 23.2 \\
\hline 2013 & 22375716.1 & 29.5 & 14841908.8 & 19.6 \\
\hline 2014 & 34250059.3 & 36.2 & 14766398.2 & 15.6 \\
\hline 2015 & 47991811.4 & 36.7 & 19042831.6 & 14.6 \\
\hline 2016 & 50462344.4 & 35.2 & 17448742.0 & 12.2 \\
\hline 2017 & 71074449.0 & 37.8 & 25242565.3 & 13.5 \\
\hline 2018 & 85428031.9 & 40.4 & 26923298.7 & 12.7 \\
\hline
\end{tabular}

The decline in the machine building share occurred due to the decrease in car production and in general its complete stop by one of the leading machine-building enterprises in the Zaporizhzhya region PJSC ZAZ, as well as due to the interruption of business ties with Russian enterprises due to the antiterrorist operation in Ukraine. The growth in the share of metallurgy occurred despite the fact that many enterprises use outdated equipment and technologies, but they have qualified personnel who provide high labor productivity to enterprises.

Let's consider a sample of data on the Zaporizhzhya region in the metallurgical industry $(X)$ and mechanical engineering $(Y)$. Figure 1 shows the scatterplots with a regression straight line and a confidence interval, which permits visualizing the correlation between two factors, namely the sales volume in the metallurgical industry and mechanical engineering within the Zaporizhzhya region. There is a strong positive correlation. This assumption is approved by the software empirical value of the correlation ratio, that is 0.914 . To analyze the strength of the relationship between the variables, the Cheddock scale was used, according to which, when the correlation ratio is above 0.9 , there is a strong relationship between the parameters under consideration.

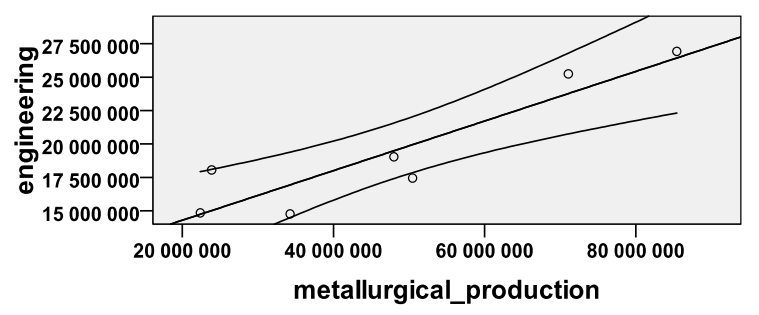

Fig. 1. Scatterplot in the Zaporizhzhya region

To define statistical reliability of the obtained value, we work with the data of corresponding Pearson's table of critical values for linear correlation ratio. For the corresponding value level $\alpha=0.01$, we find the critical value $r$, equal to 0.87 for this correlation analysis. Since the empirical value $(0.914)$ is more critical $(0.87)$, it can be concluded that the correlation ratio value is considered statistically significant. The main hypothesis about the insignificance of the correlation between qualitative signs is rejected and an alternative one is accepted. In other words, the relationship between the volume of sold manufactured products of mechanical engineering and metallurgy is statistically significant at the $1 \%$ level and is positive.

The obtained directly proportional dependence indicates that the higher the obtained correlation ratio, the higher the dependence between qualitative characteristics, and vice versa.

However, in Ukraine most of the big industrial manufactures were built in times of the Soviet Union. Based on the Report on financial results (Table 3), the volume of sold industrial products (goods, services) at PJSC "Zaporizhstal” in 2013-2017 increased by 3.4 times, and at PJSC "Motor Sich" - 1.77 times. The increase insales volume of the analyzed industrial enterprises is more associated with the rise in prices, which are caused by inflation and the hryvnia exchange rate decline, rather than with the real growth in output volumes.

Table 3. The volume of industrial products sold (goods, services) of large enterprises of the Zaporizhzhya region in 2013-2017.

\begin{tabular}{|c|c|c|}
\hline \multirow{2}{*}{ Year } & \multicolumn{2}{|c|}{ Industrial enterprise } \\
\cline { 2 - 3 } & PJSC “Zaporizhstal” & PJSC “Motor Sich” \\
\hline 2013 & 13579218 & 8583924 \\
\hline 2014 & 22110517 & 10730122 \\
\hline 2015 & 31395478 & 13830655 \\
\hline 2016 & 33158709 & 10546207 \\
\hline 2017 & 46746886 & 15150429 \\
\hline
\end{tabular}


Within the framework of two enterprises, the empirical value of the calculated ratio is 0.873 , which also indicates the statistical significance of the correlation between the volumes of goods sold in the metallurgical industry and mechanical engineering. As the relation exists, we can fore cast the values of some data based on certain values of other data (metallurgy). To put it simply, the stronger the connection, the closer our prediction will be.

To build the model, we analyzed the financial status and profitability of PJSC "Zaporizhstal" and PJSC "Motor Sich" using eight ratios selected in the model. Financial analysis of PJSC "Zaporizhstal" showed that: the absolute liquidity ratio in 2013-2017 was less than the standard value and was $0.032 ; 0.021 ; 0.034 ; 0.06 ; 0.01$, correspondingly, which indicates the irrational use of finances; solvency ratio (autonomy) of funds in 2013 increased from 0.432 to 0.499 in 2016 , and then dropped to 0.423 in 2017 , this indicator was close to the normal value only in 2016; the ratio of own working capital in 2013-2015 is below the standard, but in 2016-2017 the ratio was 0.209 and 0.18 , which is higher than the standard value, which indicates the company's financial instability in 2016-2017 and the inability to carry out active operation; the asset negotiability ratio in $2013-2017$ was approximately the same at $0.97 ; 1.19 ; 1,188 ; 0.94 ; 0.91$, respectively, which indicates the adequacy of current assets, since during the analyzed period there was a full cycle of manufacturing and circulation, as well as an equal ratio between revenues and the average annual amount of assets; the negotiability ratio of accounts payable in 20132017 amounted to $3.715 ; 3.24 ; 4.922 ; 3.703 ; 2.443$ respectively, which indicates the use of creditors' funds as a source of financing for their debtors, and another part of the finances is used by the enterprise to finance business operations; the negotiability ratio of accounts receivable in 2013-2017 amounted to 9.656; 8.488; 5.696; $3.096 ; 2.023$ respectively. That is, in 2017 compared to 2013, this indicator decreased by 4.8 times, which indicates an inefficient management of receivables in the enterprise; return on assets increased from 0.001 in 2013, 0.06 in 2014, 0.068 in 2015 to 0.133 in 2016, and in 2017 dropped to 0.07 , which indicates a decrease in assets utilization efficiency; the return on equity ratio indicates that in 2014-2017, 0.13 UAH, 0.14 UAH, 0.26 UAH and $0.14 \mathrm{UAH}$ of net profit were received for each attracted hryvnia of own funds.

The financial analysis of PJSC "Motor Sich" showed that: the absolute liquidity ratio in 2013-2017 was higher than the standard value and was $0.54 ; 0.377 ; 0.362 ; 0.616$; 0.528 respectively, which indicates a rational use of funds; the solvency ratio (autonomy) in 2013-2017 was $0.7 ; 0.649 ; 0.686 ; 0.647 ; 0.663$, respectively, which is higher than the standard value and shows a high level of solvency of the enterprise; the ratio of own working capital in 2013-2017 was $2.263 ; 1.816 ; 1.787 ; 2.871$; 3.127 respectively, which is higher than the standard, and indicates the financial stability of the company and the ability to carry out vigorous activity; the assets negotiability ratio in $2013-2017$ was $0.689 ; 0.721 ; 0.741$; $0.461 ; 0.556$, respectively, this indicates the insufficiency of current assets, since for the analyzed period there is an incomplete cycle of production and circulation; the negotiability ratio of accounts payable during 2013-2017 amounted to $24.062 ; 18.208 ; 9.802 ; 6.906 ; 15.155$ respectively, which indicates the use of creditors' funds to finance business operations; the negotiability ratio of accounts receivable in 2013-2017 amounted to 5.829; $5.699 ; 6.128 ; 4.903 ; 4.69$ correspondingly, which shows a slight decrease in the amount of receivables; the return on assets in 2013-2017 was 0.106 ; 0.105 ; 0.182 ; 0.086; 0.114 , respectively, during the researched period, the above data are at approximately the same level, and indicate how much net profit was received for each hryvnia of assets invested; return on equity ratio in 20132017 was $0.154 ; 0.156 ; 0.272 ; 0.129 ; 0.174$ respectively, and it shows how much net profit was received for each attracted hryvnia of own funds.

In our opinion, the assessment of economic security level should be based not only on indicators of financial condition, but also on an assessment of bankruptcy possibility of an enterprise, i.e. there is a correlation between these categories.

Modern scholars when conducting financial analysis widely use foreign approaches to predict the probability of bankruptcy of an industrial enterprise, namely the Altman model. From 2013 to 2017, the calculation results for the Altman model showed a low probability of bankruptcy at PJSC "Zaporizhstal”, namely: 3.756; 4.071; 4.302; 4.712; 4.874, respectively, and at PJSC "Motor Sich", namely: 7.042; 6.829; 10.508; 5.321; 5.74 respectively, which is a consequence of the stable financial condition of enterprises (Table 4).

Table 4. Analysis of the likelihood of bankruptcy of large enterprises of the Zaporizhzhya region in 2013-2017 using the Altman model.

\begin{tabular}{|c|c|c|}
\hline \multirow{2}{*}{ Year } & \multicolumn{2}{|c|}{ Industrial enterprise } \\
\cline { 2 - 3 } & PJSC “Zaporizhstal" & PJSC “Motor Sich" \\
\hline 2013 & 3,756 & 7,042 \\
\hline 2014 & 4,071 & 6,829 \\
\hline 2015 & 4,302 & 10,508 \\
\hline 2016 & 4,712 & 5,321 \\
\hline 2017 & 4,874 & 5,740 \\
\hline
\end{tabular}

The use of foreign models to define the probability of bankruptcy in Ukraine is not quite correct, since they are built on the experience of foreign companies. It is very different from the working conditions of domestic enterprises and the threshold values of the standard are defined on the basis of the past of foreign companies' activity.

Analysis of bankruptcy probability of twenty-nine Zaporizhzhya industrial enterprises for over 5 years using seven selected models of Altman, Springate, Taffler and Tishou, Saifulin-Kadykov, Lis, Conan, Golder and Beaver showed that using these models in practice gives the opposite results, namely, according to one model - a low probability, and to the other - a high probability of bankruptcy. Therefore, after analyzing the existing foreign models, we built our own improved model for estimating the probability of bankruptcy for Ukrainian companies, using data from their financial statements. 
The problem of applying a larger period sample is complicated by the fact that in 2013 the National Regulation (Standard) of Accounting 1 "General Requirements for Financial Reporting" was approved with new forms of financial reporting. Financial statements of enterprises must be submitted to the state fiscal service before March 1 of a current year, and to statistics bodies - by February 28 of a present year, and put it in the official website until April 30, therefore the data range for analysis is selected from 2013 to 2017.

Most often, scientists suggest discriminatory models for evaluating the probability of bankruptcy for use in practice, but these models are not perfect for evaluating Ukrainian enterprises lately, since the correctness of their results depends on the period and year of the selected statements for financial analysis. Most of the models were derived earlier and they are not adapted to the financial reporting form, which was changed in 2013. We took the Safulin-Kadykov approach as a basis, where the author chose 5 financial statements indicators, namely, the coefficients: providing with own funds, current liquidity, asset turnover, profitability of sales and equity.

According to the results of the analysis of the reporting of the studied industrial enterprises, we selected 8 significant indicators, in our opinion, that most characterize their financial condition. We selected several key indicators from each group that best reflect the real state of the company, namely the groups: liquidity, solvency, business activity and profitability. The main criterion for the selection of indicators was the availability of different source data for their calculation in the financial statements of the company.

According to the results of the analysis of existing domestic and foreign models of bankruptcy probability in the context of these Zaporizhzhya regional industrial enterprises, the improved model is proposed, which is founded on the impact of the most valuable ratios of financial analysis and profitability. The resulting model for predicting the bankruptcy probability includes eight ratios of financial analysis and profitability, and has the following form:

$$
Z=0.5 x_{1}+0.3 x_{2}+x_{3}+0.3 x_{4}+0.01 x_{5}+0.05 x_{6}+0.3 x_{7}+0.3 x_{8}
$$

where $x_{1}$ - the absolute liquidity ratio; $x_{2}$ - solvency ratio (autonomy); $x_{3}$ - the ratio of own working capital; $x_{4}-$ assets negotiability ratio; $x_{5}$ - negotiability ratio of accounts payable; $x_{6}-$ negotiability ratio of receivables; $x_{7}$ - asset profitability ratio; $x_{8}$ - ratio of return on equity.

Using discriminant analysis based on the results of practical data processing at twenty-nine industrial enterprises over the past five years, the coefficients to the selected eight indicators were determined using the SPSS Statistics system. On the basis of the obtained correlation coefficient between these indicators, it was established that there is a low relationship between them.

Approbation of the improved model made it possible to group the results of predicting the probability of bankruptcy in four ranges. The results of the model obtained and the boundaries of the range were verified with real data on the financial condition of enterprises.
In contrast to the existing models, in the bankruptcy probabilities evaluating scales with either two values (high and low) or three (high, medium or uncertain, and low), there defined four groups of values, namely: very low, low, possible and high bankruptcy probability. The resulting range of values is: if $x>1.3$ - very low enterprise bankruptcy probability, if $0.6<x<1.3$ - low enterprise bankruptcy probability, if $0<x<0.6$ - possible enterprise bankruptcy probability, if $x<0-$ high enterprise bankruptcy probability.

According to the results of the proposed model of bankruptcy in 2013-2017, PJSC "Motor Sich" was in the first group with a very low bankruptcy probability and in 2013-2017 PJSC “Zaporizhstal” fell into the second group with a low bankruptcy probability, which fully corresponds to the real data.

\section{Conclusions}

In this paper, the volume of sold industrial products (goods, services) was analyzed according to types of economic growth in Ukraine and Zaporizhzhya region, as well as two large industrial manufactures of Zaporizhzhya region. The evaluation of correlation link between values under analyses was conducted.

Based on the data of PJSC "Zaporizhstal" and PJSC "Motor Sich", a financial analysis was conducted for the years 2013-2017. The Financial Report showed that in 2013-2017 PJSC "Zaporizhstal" sold its industrial products (goods, services) 3.4 times more. PJSC "Motor Sich" production increased by 1.77 times. It was noted that the increase in sales volume of the analyzed industrial enterprises is more related to prices increase caused by inflation and the hryvnia exchange rate decline, and not to the real growth in the output volume.

According to the analysis of existing models of bankruptcy probability in the context of industrial enterprises of Ukraine, the authors proposed an improved assessing model based on the influence of the most significant ratios of financial analysis. Estimation of the main criteria for the quality of the model confirmed that the percentage of bankruptcies and stable activities foreseen are acceptable and indicate a high quality of the resulting equation. This will permit to use it in the diagnostic practice of the bankruptcy probability of industrial enterprises. Timely identification of problems will help to make management decisions on time, ensuring the stability of industrial enterprises that will impact the welfare of the area and Ukraine as a whole.

\section{References}

1. Andryushchenko, I.S.: Analiz sotsial'noekonomichnykh pokaznykiv rozvytku promyslovosti Ukrayiny (Analysis of socio-economic indicators of industrial development in Ukraine) Naukovyy visnyk Mizhnarodnoho humanitarnoho universytetu. Seriya: Ekonomika i menedzhment. 23(1), 86-90 (2017).

2. Sitak, I.L., Korobkov, D.V., Mishchenko, V.A.: Sovremennyye metody opredeleniya ustoychivosti predpriyatiya (Modern methods for determining the 
sustainability of an enterprise). Business Inform. 9, 92-98 (2012)

3. Vasin, S.M., Hamidullaeva, L.A., Finogeev, A.G., Mkrtchyan, V.S., Berezin, A.A., Palatkin, I.V.: Sotsial'nyye media kak indikator tsifrovoy aktivnosti i tsifrovoy zrelosti naseleniya (Social media as an indicator of digital activity and digital maturity of the population). Problems of the modern economy. 3(67), 32-39 (2018)

4. Moschenok, V.V: Ispol'zovaniye neyronnykh setey dlya modelirovaniya zavisimostey parametrov investitsionnykh proyektov (Using neural networks for modeling the dependencies of the parameters of investment projects). Donetsk, Donetsk National Technical University, 54-60 (2012)

5. Galushkin, A.I.: Gde primenyayut neyrokomp'yutery $\mathrm{v}$ finansovoy deyatel'nosti (Where neurocomputers are used in financial activities). https://neuronus.com/stat/175-primeneniyanejrokompyuterov-v-finansovoj-deyatelnosti.html (2019). Accessed 21 Mar 2019

6. Khlystova, O.V.: Strategicheskoye upravleniye na osnove neyrosetevogo modelirovaniya (Strategic management based on neural network modeling). Management in Russia and Abroad. 3, 18-24 (2011)

7. Mints, A.Yu., Bezzubkova, E.E.: Metody prognozirovaniya kolichestva bankrotstv v Ukraine (Methods for predicting the number of bankruptcies in Ukraine). Economics and management organization. 1(17)/2(18), 174-181 (2014)

8. Veselý, A.: Economic classification and regression problems and neural networks. Agric. Econ. Czech. 57, 150-157 (2011)

9. Abounoori, E., Bagherpour, M.: Estimation of industrial production costs, using regression analysis, neural networks or hybrid neural-regression method. Iranian Economic Review. 11(2), 17-29 (2005)

10. Angelidis, D., Lyroudi, K., Koulakiotis, A.: Forecasting Daily Returns: A Comparison Of Neural Networks With Parametric Regression Analysis. International Business \& Economics Research Journal. $\quad 5(1), \quad 75-82 \quad$ (2006). doi:10.19030/iber.v5i1.3451

11. Barndorff-Nielsen, O.E., Shephard, N.: Econometric Analysis of Realised Covariation: High Frequency Covariance, Regression and Correlation in Financial Economics. Econometrica. 72(3), 885-925 (2002). doi:10.2139/ssrn.305583

12. Khalikova, E., Lebert, T., Butusov, E.: Ispol'zovaniye instrumentariya matematicheskoy statistiki dlya prognozirovaniya investitsionnoinnovatsionnogo potentsiala Respubliki Bashkortostan (Using the tools of mathematical statistics to predict the investment and innovation potential of the Republic of Bashkortostan). Economics and management. 6, 49-55 (2014)

13. Raevneva, E. V., Gorokhovaya, O. I.: Formirovaniye indikativnykh znacheniy pokazateley raspoznavaniya klassa krizisa promyshlennykh predpriyatiy
(Formation of indicative values of indicators of recognition of the crisis class of industrial enterprises). Business Inform. 7(2), 21-23 (2011)

14. Ponomarenko, E.E.: Ispol'zovaniye nechotkikh mnozhestv pri otsenke finansovoy bezopasnosti sub'yektov khozyaystvovaniya promyshlennosti (The use of fuzzy sets in assessing the financial security of industrial entities). Business Inform. 9, 109-113 (2012)

15. Altman, E. J.: Financial Ratios, Discriminant Analysis and the Prediction of Corporate Bankruptcy. Journal of Finance. 4, 589-609 (1968)

16. Beaver, W.: Financial Ratios as Predictors of Failure. Empirical Research in Accounting, Selected Studies. Journal of Accounting Research. 4, 71-111 (1966)

17. Toffler, R., Tishaw, H.: Going, going, gone - four factors which predict. Accountancy. 88, 50-54 (1977)

18. Kondrashuhin, A., Pepa, T. \& Fedorova, V.: Finansova sanatsia ta bankrutstvo pidpryiemstv [Financial reorganization and enterprise bankruptcy]. Tsentr navchalnoi literatury, Kyiv (2007)

19. Gmurman, V.Ye.: Teoriya veroyatnostey i matematicheskaya statistika (Probability theory and mathematical statistics). Vysshaya shkola, Moscow (1972) 